Bull. Environ. Contam. Toxicol. (2005) 74:769-776

(C) 2005 Springer Science+Business Media, Inc.

DOI: $10.1007 / \mathrm{s} 00128-005-0648-5$

\title{
Toxicity of Pendimethalin to Nontarget Soil Organisms
}

\author{
J. B. Belden, T. A. Phillips, B. W. Clark, J. R. Coats
}

Department of Entomology, lowa State University, Ames, IA 50014, USA

Received: 26 August 2004/Accepted: 19 January 2005

Pendimethalin, 1-ethylpropyl-3,4-dimethyl-2,6-dimethyl-dinitrobenzeneamine, is an extensively used dinitroanaline herbicide. In 1997, 25-30 million pounds of pendimethalin were applied to agricultural and nonagricultural sites within the United States (USEPA 1997). The half-life of pendimethalin in soil can be very long; at $10^{\circ} \mathrm{C}$ the half-life for pendimethalin was reported to be over 400 days (Walker and Bond 1977). Pendimethalin is one of the only current use pesticides to be placed on the United States Environmental Protection Agency's Persistent, Bioaccumulatory, and Toxic list as part of the Toxic Release Inventory (USEPA 1999). Despite heavy usage and environmental persistence, little information is available regarding the effects of pendimethalin on non-target soil organisms. Thus, the objective of this study was to evaluate the toxicity of pendimethalin to four non-target plant species and three invertebrate animal species.

\section{MATERIALS AND METHODS}

Technical grade pendimethalin was obtained in kind from American Cyanamid (currently BASF, Research Triangle Park, NC, USA). It was purified to greater than $98 \%$ purity by column chromatography using silica gel as a stationary phase and hexane:acetone 95:5 as a mobile phase. Purity was checked based on gas chromatography coupled with flame ionization detection.

Three prairie grass species were chosen for testing due to their potential use in remediation and restoration of pesticide-contaminated sites (Belden et al. 2004). Seed for all three species, big bluestem (Andropogon gerardii; Pawnee variety), yellow indiangrass (Sorghastrum nutans; Holt variety), and switchgrass (Panicum vergatum; Pathfinder variety) was purchased from United Seed Company (Omaha, NE, USA). The fourth plant species, lettuce (Lactuca sativa), was chosen as a standard test reference. Lettuce seed was obtained from Carolina Biological (Burlington, NC, USA). Purity for all seeds was greater than $97 \%$.

The three animal species, springtails (Folsomia candida Willem), earthworms (Eisenia fetida), and pill bugs (Armadillidium sp.) were selected based on their importance in soil for turnover of decaying plant material and other soil processes. Springtail cultures were obtained from Oklahoma State University,

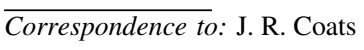


Ecotoxicology and Water Quality Laboratory (Stillwater, OK, USA). The organisms originated from Dr. Renata Snyder, Michigan State University (Lansing, MI, USA). They were cultured in our laboratory for two years prior to toxicity testing. Culturing was performed as previously described (Wiles and Krogh 1998), on a hydrated $\mathrm{CaSO}_{4}$, activated-charcoal medium using baker's yeast as a food source. Twenty-day old organisms were used in testing.

Earthworms were acquired from a local vender and cultured for over three years prior to these bioassays. Culturing was conducted by adding 10 adults each to $3-$ L square containers filled with a mixture of potting soil and horse manure (collected from a horse known to not be medicated). Prior to starting the earthworm bioassays, approximately 50 cocoons (egg cases) were removed from three different culturing containers and placed in potting soil in a fresh container. At test time, young worms, $7-20 \mathrm{mg}$ in size were collected from this container.

Pill bugs were wild-caught in a greenhouse bay at Iowa State University that had not received pesticide treatment for longer than four years. Captured organisms were divided based on gross morphological characteristics. A large number of organisms with similar morphology were identified to be in the genus Armadillidium. Pill bugs were held in captivity greater than 45 days prior to use in bioassays.

Each bioassay was conducted using agronomic soil from a reference site that has not received pesticide usage in over 10 years (Field 55, Iowa State University Agronomy-Ag Engineering Research Farm, Ames, IA, USA). The soil was sieved $(2.8 \mathrm{~mm})$ to remove plant material and rocks. Analysis of the soil indicated a sandy loam texture ( $60 \%$ sand, $22 \%$ silt, and $18 \%$ clay), $2.7 \%$ organic matter, and a pH of 7.0 (Midwest Laboratories, Omaha, Nebraska, USA). Field capacity was determined to be $17 \%$ (water/dry soil). Soil was allowed to air-dry to greater than $97 \%$ solid, followed by moistening to near field capacity, and then allowed to air-dry again. This procedure was intended to reduce soil fauna to prevent competition or predation of the test organisms.

Toxicity tests were performed by placing soil in $7.0 \times 4.0$-cm glass jars $(20,25,8$, $12 \mathrm{~g}$ of soil for plants, earthworms, springtails, and pill bugs, respectively). Soil was then treated within each jar using $100 \mu$ l of acetone carrier. Jars were allowed to set open overnight to allow for the evaporation of acetone, prior to starting toxicity tests. At least four concentration levels were used per test, using concentrations based on preliminary studies. In addition, solvent controls were conducted. For plant testing, three replicate jars were performed at each pendimethalin concentration and for controls. For animal tests, twenty replicate jars were used. Moisture levels were maintained at field holding capacity throughout the study based on a gravimetric basis.

Toxicity to plants was assessed using 14-day seedling growth assays (prairie grasses) and 7-day growth assays (lettuce). Ten seeds were planted in each jar and at the end of the study, seedlings were carefully removed from the soil and 
length of the entire seedling was measured. Jars were kept at greenhouse conditions.

Springtail tests were conducted by adding a single springtail to each jar. Twenty replicate jars were conducted for each pendimethalin concentration and controls. Tests lasted for 28 days at $20^{\circ} \mathrm{C}$ and a 16:8 light:dark cycle. Brown paper separated the test chambers from the light source, thus reducing light exposure. During the test, moisture and food ( 2 granules of baker's yeast) were checked every 72 hours. Every 3-4 days, adult survival and presence of offspring was recorded. At the end of the study, soil was gently flooded with reagent water saturated with sucrose. The container was exposed to ethyl acetate fumes to anesthetize the springtails and then the springtail populations were counted under a magnifying glass.

Earthworm studies were conducted using an endpoint of juvenile growth. Single worms were dipped in reagent water, blotted dry with a paper towel, weighed to the nearest $0.1 \mathrm{mg}$, and added to a jar. A fine layer $(50 \mathrm{mg}$ ) of cerophyll (ground cereal leaf material) was applied to the top of the soil every seven days (in total $0.75 \%$ of the soil mass) to feed the worms. Test chambers were kept at $23^{\circ} \mathrm{C}$, in the dark. During the test only two worms were noted out of the soil, both in the highest treatment level. After 21 days, the degree of soil disruption was noted as either total disruption of surface or not. The earthworms were dipped in reagent water, blotted dry with a paper towel, and weighed. In addition, an aliquot of soil from earthworm bioassays pre- and post-test was mixed with an equal mass of deionized/reverse osmosis-treated water to determine soil $\mathrm{pH}$.

For measurement of pill bug lethal effects, a single pill bug was added to each test container. Each pill bug was fed a rectangular piece of fresh, green corn leaf $(0.5$ $x 1.0 \mathrm{~cm}$ ). At 3-4 day intervals, moisture in each container was adjusted to field capacity, and the food was replaced. Consumption was noted based on disruption of the margins of the corn leaf - any disruption was considered a positive response. Survival and the position of the pill bug in the soil (under the soil surface versus on the soil surface) also were noted. Additional information, such as molting and reproduction, was noted. After 14 days, pill bugs were removed and observed for the ability to unroll from the ball position and move their legs; pill bugs unable to do this were recorded as dead.

One additional test chamber was constructed for each treatment in each test to provide soil for analysis and verification of pendimethalin concentrations. In addition, after each test, soil from three test containers was combined to form a single sample for each treatment in each test. Each soil sample was placed in $200-\mathrm{ml}$ jars with $4: 1$ by volume of ethyl acetate: mass of soil, which was shaken vigorously for 20 minutes. The solvent was removed and filtered, and the process was repeated twice. The combined extracts were evaporated to a $5-\mathrm{ml}$ final volume under a stream of nitrogen. The extract was analyzed by gas chromatography coupled with thermionic specific detection (GC-TSD, nitrogen and phosphorous specific; Varian 3400, Walnut Creek, CA). Extraction 
efficiency for this method was $95 \%($ SD $11, \mathrm{n}=5$ ) for pendimethalin and the limit of detection was $0.2 \mathrm{mg} / \mathrm{kg}$.

Analysis of variance (ANOVA) was used in combination with Fisher's PLSD $(p<0.05)$ to determine if pendimethalin had a significant effect and which concentrations differed from controls for continuous data. Categorical data were analyzed using Chi Square analyses using the control as the expected outcome. Computations were made using Statview for Windows (1998). Inhibition concentrations and effective concentrations were determined using the Trimmed Spearman-Karber method (Hamilton et al. 1977). Standard errors (1 standard error from the mean, SE), or standard deviation (1 standard deviation from the mean, SD) where appropriate, are reported in parentheses following all mean values.

\section{RESULTS AND DISCUSSION}

Pendimethalin soil concentrations were consistent throughout all experiments. All control samples were less than $0.2 \mathrm{mg} / \mathrm{kg}$. Pretest samples ranged from 92$125 \%$ of targeted values. Post-test values in the springtail and earthworm studies ranged from 78-90\% of applied. Pill bug and seedling growth studies ranged from $85-109 \%$ of targeted values. Although soil concentrations were stable, bioavailability may have decreased over the length of the study, especially in earthworm tests in which the soil was highly processed and organic material was added.

Pendimethalin significantly inhibited seedling growth for all species tested $(\mathrm{F}=17$ to $112, \mathrm{p}<0.001)$. The highest concentration not significantly different from the control is reported in Table 1 as the no observed effects concentration (NOEC) and the lowest concentration that was significant is reported as the lowest observed effects concentration (LOEC, $\mathrm{p}<0.05$ ). For both big bluestem and yellow indiangrass, the lowest concentration tested elicited a significant effect $(p<0.05)$ preventing determination of a NOEC. Switchgrass and lettuce were less sensitive than yellow indiangrass and big bluestem; however growth in all species was inhibited at concentrations less than $10 \mathrm{mg} / \mathrm{kg}$. This concentration represents the highest application rate of pendimethalin $(4 \mathrm{~kg} / \mathrm{ha})$ distributed through the top $4 \mathrm{~cm}$ of the soil column. Due to the low mobility of pendimethalin, this is a worst-case, although obtainable, concentration due to normal application.

Germination rates were greater than $90 \%$ for all lettuce treatments up to concentrations of $64 \mathrm{mg} / \mathrm{kg}$. At $256 \mathrm{mg} / \mathrm{kg}$ germination did not occur. Germination rates in the low-level prairie grass treatments $(1$ and $4 \mathrm{mg} / \mathrm{kg}$ ) were variable ranging from $60-90 \%$ and were not significantly different from controls. Due to the low germination rate in prairie grasses, LOEC and NOEC values were not considered valid for this endpoint. Complete inhibition of germination occurred for yellow indiangrass and big bluestem at $16 \mathrm{mg} / \mathrm{kg}$ and at $64 \mathrm{mg} / \mathrm{kg}$ for switchgrass. 
Table 1. Toxicity of pendimethalin to selected soil organisms.

\begin{tabular}{|c|c|c|c|c|c|}
\hline Species & $\begin{array}{l}\text { Length } \\
\text { of Test }\end{array}$ & Endpoint & $\begin{array}{l}\text { NOEC } \\
\text { mg/kg }\end{array}$ & $\begin{array}{c}\mathrm{LOEC} C^{\mathrm{b}} \\
\mathrm{mg} / \mathrm{kg}\end{array}$ & $\begin{array}{c}\mathrm{IC}_{50} \text { or } \mathrm{LC}_{50}^{\mathrm{c}} \text {, } \\
\mathrm{mg} / \mathrm{kg} \\
(95 \% \text { C.I. })\end{array}$ \\
\hline $\begin{array}{c}\text { Lettuce } \\
\text { Latuca sativa }\end{array}$ & 7 day & $\begin{array}{l}\text { Seedling } \\
\text { growth }\end{array}$ & 1.0 & 4.0 & $\begin{array}{c}7.74 \\
(5.67-10.57)\end{array}$ \\
\hline $\begin{array}{l}\text { Switchgrass } \\
\text { Panicum } \\
\text { vergatum }\end{array}$ & 14 day & $\begin{array}{l}\text { Seedling } \\
\text { growth }\end{array}$ & 1.0 & 4.0 & $\begin{array}{c}6.23 \\
(4.68-8.28)\end{array}$ \\
\hline $\begin{array}{l}\text { Big Bluestem } \\
\text { Andropogon } \\
\text { gerardii }\end{array}$ & 14 day & $\begin{array}{l}\text { Seedling } \\
\text { growth }\end{array}$ & $\mathrm{NC}^{d}$ & 1.0 & $\begin{array}{c}1.09 \\
(0.72-1.66)\end{array}$ \\
\hline $\begin{array}{c}\text { Yellow } \\
\text { Indiangrass } \\
\text { Sorghastrum } \\
\text { mutans }\end{array}$ & 14 day & $\begin{array}{l}\text { Scedling } \\
\text { growth }\end{array}$ & $\mathrm{NC}$ & 1.0 & $\begin{array}{c}1.33 \\
(0.84-2.13)\end{array}$ \\
\hline $\begin{array}{l}\text { Springtail } \\
\text { Folsomia } \\
\text { candida }\end{array}$ & 28 day & $\begin{array}{l}\text { Reproduction- } \\
\text { Number } \\
\text { offspring } \\
\text { produced }\end{array}$ & 30 & 90 & $\begin{array}{c}47 \\
(44-51)\end{array}$ \\
\hline $\begin{array}{c}\text { Earthworm } \\
\text { Eisenia fetida }\end{array}$ & 21 day & $\begin{array}{l}\text { Growth-Early } \\
\text { Life Stage }\end{array}$ & $\mathrm{NC}$ & 10 & $\begin{array}{c}113 \\
(84-115)\end{array}$ \\
\hline $\begin{array}{c}\text { Pillbug } \\
\text { Armadillidium }\end{array}$ & 14 day & Survival & 200 & $\mathrm{NC}$ & $>200$ \\
\hline
\end{tabular}

NOEC- no observable effects concentration. BOEC- lowest observable effects concentration. ${ }^{c} \mathrm{IC}_{50^{-}}$concentration necessary to cause a $50 \%$ inhibition of growth or reproduction or $\mathrm{LC}_{50^{-}}$ concentration necessary to cause a $50 \%$ reduction in survival. C.I.-confidence interval. ${ }^{\mathrm{N}} \mathrm{NC}$ - not calculated due to inadequate data. "ELS- early life stage test.

Other researchers have found similarly high toxicity for other plant species. Plant height of ryegrass was inhibited by $25 \%$ at $0.10 \mathrm{~kg} / \mathrm{ha}$, and onion survival was reduced $25 \%$ by $1.4 \mathrm{~kg} / \mathrm{ha}$ (USEPA 1997). However, researchers investigating potential use of the prairie grass species for phytoremediation have successfully transplanted plugs of grass into soil containing over $100 \mathrm{mg} / \mathrm{kg}$ of aged pendimethalin residues (Belden 2003). With effort, tolerant species may be transplanted into soil moderately contaminated with pendimethalin.

Pendimethalin significantly reduced the percentage of springtails capable of reproducing (for the highest treatment compared to control, $\mathrm{X}^{2}=33, \mathrm{p}<0.001$; no other treatments were significant) and the number of offspring produced per springtail $(\mathrm{F}=25, \mathrm{p}<0.001)$. Both the LOEC and the NOEC are shown in Table 1 . The $\mathrm{IC}_{50}$ for both endpoints was also nearly identical, measuring at $54 \mathrm{mg} / \mathrm{kg}$ for 


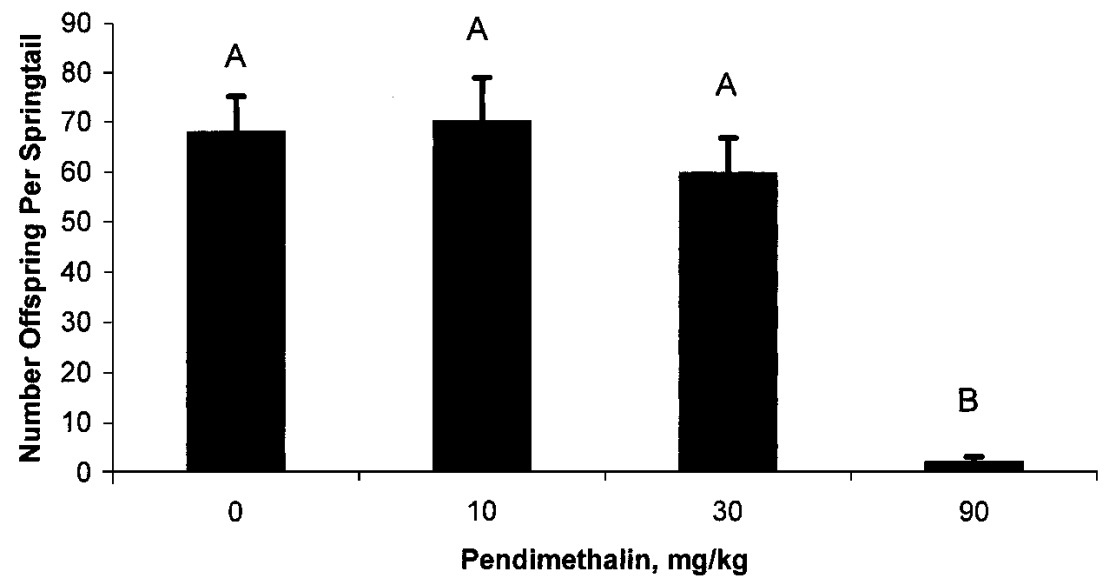

Figure 1. Effect of pendimethalin on the number of offspring produced per springtail. Treatments not marked with the same letter are significantly different $(p<0.05)$. Error bars represent one standard error.

percentage reproducing and $47 \mathrm{mg} / \mathrm{kg}$ for number of offspring produced. Figure 1 provides the mean number of offspring recovered at the end of the experiment for each treatment. For both endpoints, little to no effect occurs at concentrations up to $30 \mathrm{mg} / \mathrm{kg}$ followed by a dramatic decrease in reproductive success at $90 \mathrm{mg} / \mathrm{kg}$. No mortality was observed in any springtail treatments despite the fact that springtails in the highest concentration became yellow, presumably due to uptake of pendimethalin which is highly yellow/orange colored.

Earthworms obtained substantial growth during the 3-week study with an average increase in controls of over $1500 \%$. Pendimethalin significantly decreased weight gain $(\mathrm{F}=17, \mathrm{p}<0.001)$; even the lowest treatment, $10 \mathrm{mg} / \mathrm{kg}$, was significantly different from the control $\left(\mathrm{p}<0.05\right.$; Figure 2). The NOEC, LOEC, and $\mathrm{IC}_{50}$ are shown in Table 1. No mortality was found in the control or the $10 \mathrm{mg} / \mathrm{kg}$ treatment. Five and ten percent mortality was recorded in the 40 and $160 \mathrm{mg} / \mathrm{kg}$ treatments, respectively. Since $10 \mathrm{mg} / \mathrm{kg}$ could be obtained during normal application, some concern may be warranted in regards to the impact of pendimethalin on earthworm populations after application using the highest labeled rates. However, it is unclear whether any population decreases would occur due to a $17 \%$ decrease in weight gain. In addition, the degree of soil processing was also measured as a subjective evaluation of earthworm feeding and activity. This endpoint was less sensitive than growth. The $10 \mathrm{mg} / \mathrm{kg}$ treatment was not significantly different from controls (80-85\% disturbed). At 40 $\mathrm{mg} / \mathrm{kg}$, significantly fewer experimental units had completely disturbed soil $(58 \%$, $X=5.9, p=0.02)$, and at $160 \mathrm{mg} / \mathrm{kg}$ only $22 \%$ of the soil had been disturbed $(X=13$, $\mathrm{p}<0.001)$. 


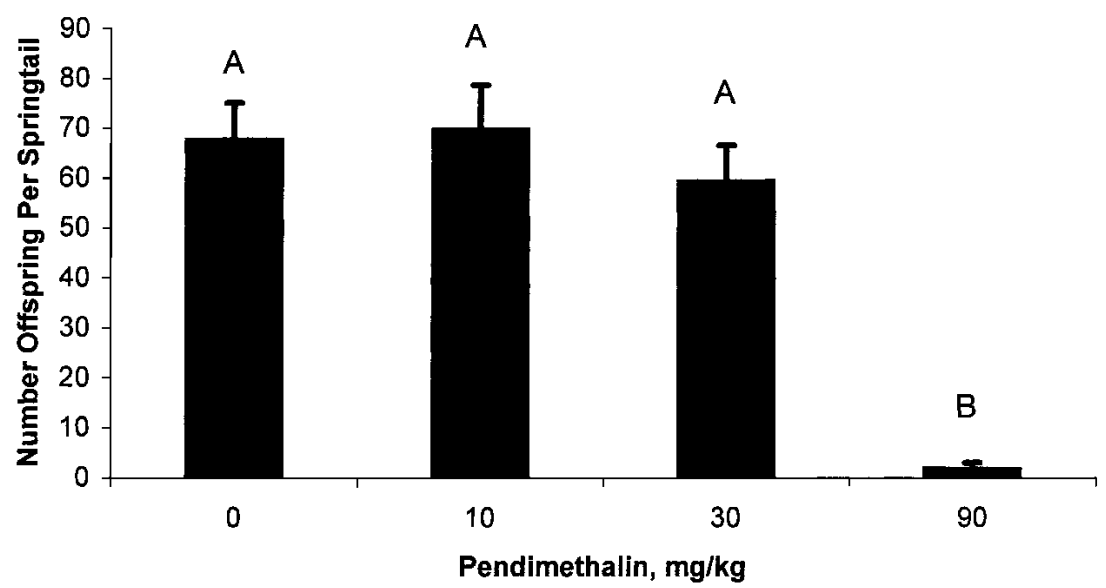

Figure 1. Effect of pendimethalin on the number of offspring produced per springtail. Treatments not marked with the same letter are significantly different $(p<0.05)$. Error bars represent one standard error.

percentage reproducing and $47 \mathrm{mg} / \mathrm{kg}$ for number of offspring produced. Figure 1 provides the mean number of offspring recovered at the end of the experiment for each treatment. For both endpoints, little to no effect occurs at concentrations up to $30 \mathrm{mg} / \mathrm{kg}$ followed by a dramatic decrease in reproductive success at $90 \mathrm{mg} / \mathrm{kg}$. No mortality was observed in any springtail treatments despite the fact that springtails in the highest concentration became yellow, presumably due to uptake of pendimethalin which is highly yellow/orange colored.

Earthworms obtained substantial growth during the 3-week study with an average increase in controls of over $1500 \%$. Pendimethalin significantly decreased weight gain $(F=17, p<0.001)$; even the lowest treatment, $10 \mathrm{mg} / \mathrm{kg}$, was significantly different from the control $\left(\mathrm{p}<0.05\right.$; Figure 2). The NOEC, LOEC, and $\mathrm{IC}_{50}$ are shown in Table 1. No mortality was found in the control or the $10 \mathrm{mg} / \mathrm{kg}$ treatment. Five and ten percent mortality was recorded in the 40 and $160 \mathrm{mg} / \mathrm{kg}$ treatments, respectively. Since $10 \mathrm{mg} / \mathrm{kg}$ could be obtained during normal application, some concern may be warranted in regards to the impact of pendimethalin on earthworm populations after application using the highest labeled rates. However, it is unclear whether any population decreases would occur due to a $17 \%$ decrease in weight gain. In addition, the degree of soil processing was also measured as a subjective evaluation of earthworm feeding and activity. This endpoint was less sensitive than growth. The $10 \mathrm{mg} / \mathrm{kg}$ treatment was not significantly different from controls (80-85\% disturbed). At 40 $\mathrm{mg} / \mathrm{kg}$, significantly fewer experimental units had completely disturbed soil $(58 \%$, $\mathrm{X}=5.9, \mathrm{p}=0.02)$, and at $160 \mathrm{mg} / \mathrm{kg}$ only $22 \%$ of the soil had been disturbed $(X=13$, $\mathrm{p}<0.001)$. 
In conclusion, persistent levels of pendimethalin at field application levels (10 $\mathrm{mg} / \mathrm{kg}$ and below) will likely impact plant communities. However, invertebrate communities are generally more tolerant to pendimethalin. At field application levels, springtail reproduction was not affected and only a slight reduction was noted in earthworm growth. However, pendimethalin at a concentration 9X above field application resulted in nearly complete disruption of springtail reproduction and at $16 \mathrm{X}$ above the field application rate, pendimethalin reduced earthworm growth by $60 \%$. Thus, only a relatively small safety margin exists indicating that over-application or point source contamination (such as spillage) could impact plant and invertebrate communities.

\section{REFERENCES}

Belden JB, Clark BW, Phillips TA, Henderson KL, Coats JR (2003) Detoxification of Pesticide Residues in Soil Using Phytoremediation. J. Gan (ed.) Remediation of Pesticides. American Chemical Society, Washington, D.C.

Belden JB, Phillips TR, Coats JR (2004) Effect of prairie grass on the dissipation, movement, and bioavailability of selected herbicides in prepared soil columns. Environ Toxicol Chem. In press.

Farenhorst A, Tomlin AD, Bowman BT (2003) Impact of herbicide application rates and crop residue type on earthworm weights. Bull Environ Contam Toxicol 40:477-484.

Hamilton MA, Russo RC, Thurston RV (1977) Trimmed Spearman-Karber method for estimating median lethal concentrations in toxicity bioassays. Environ Sci Technol 11:714-719; Correction 12:417 (1978)

Kelsey JW, Alexander M (1997) Declining bioavailability and inappropriate estimation of risk of persistent compounds. Environ Toxicol Chem 16:582585

Statview for Windows (1998) The SAS Institute, Cary, NC, USA

Sverdrup LE, Jensen J, Krogh PH, Stenersen J (2002) Studies on the effect of soil aging on the toxicity of pyrene and phenanthrene to a soil-dwelling springtail. Environ Toxicol Chem 21:489-492.

United States Environmental Protection Agency (1997) Pendimethalin reregistration eligibility decision (RED). Office of Pesticides, EPA 738-R-97007 . June 1997.

United States Environmental Protection Agency (1999) Persistent bioaccumulative toxic (PBT) chemicals; final rule. Federal Register. 40 CFR Part 372. Friday October 29, 1999.

Walker A, Bond W (1977) Persistence of the herbicide AC 92, 55, N-(1ethylpropyl)-2,6-dinitro-3,4-xylidine in soils. Pestic Sci 8:359-365.

Wiles JA, Krogh PH (1998) Test with the Collembolans Isotoma viridis, Folsomia candida and Folsomia fimetaria. In: Lokke $\mathrm{H}$ and van Gestel CAM (eds) Handbook of Soil Invertebrate Toxicity Tests. John Wiley \& Sons, New York, NY, USA. 